\title{
Non-Structural Mitigation Through Media Literacy on Cyclone Disaster in West Muna Regency
}

\section{Mitigasi Non Struktural Melalui Literasi Media Pada Bencana Angin Puting Beliung Di Kabupaten Muna Barat}

\section{Dina Ruslanjari ${ }^{1}$, Titis Puspita Dewi $^{2}$, and Anisa Eka Puspitasari $i^{3}$}

${ }^{1}$ Master Study Program Disaster Management, Graduate School, Universitas Gadjah Mada; Teknika Utara Road, Pogung, Sleman

${ }^{2}$ Alumni of Master Study Program Extension and Communication Development, Graduate School, Universitas Gadjah Mada; Teknika Utara Road, Pogung, Sleman

${ }^{3}$ Student of Master Study Program Disaster Management, Graduate School Universitas Gadjah Mada; Teknika Utara Road, Pogung, Sleman

Corresponding Author:

Dina Ruslanjari

dienarus@ugm.ac.id

Received: 14 July 2019

Accepted: 29 July 2016

Published: 4 August 2019

Publishing services provided by

Knowledge E

(c) Dina Ruslanjari et al. This article is distributed under the terms of the Creative Commons Attribution License, which permits unrestricted use and redistribution provided that the original author and source are credited.

Selection and Peer-review under the responsibility of the IGSSCI Conference Committee.

\section{Abstract}

Cyclone disaster is the second most deadly disaster in Indonesia after flooding. Cyclones mostly occur during the transitional period from dry season to rainy season. West Muna Regency is one of the regions which started to experience cyclones as a disaster in 2015 where they experienced the most immense disaster that has occurred on record. This disaster caused 600 houses in three districts namely North Tiworo District, South Tiworo District, and Tiworo Archipelago District to be heavily damaged. The magnitude of the disaster was caused by the distribution of area in the three districts which are generally comprised of floating villages far from Muna Island mainland. Cyclone disasters which occur in West Muna Regency requires attention in which one form is non-structural mitigation. Non-structural mitigation can be embodied in the forms of law formulation, formulation of a hazard map, formulation of a risk map, zonation, education, counseling, and emerging awareness toward the community. The focus of this research was recommending the implementation of non-structural mitigation through media literacy, which is categorized as establishing awareness within the community. This research as aimed to enhance the awareness and knowledge of the community related to cyclone disaster. The research method used was a qualitative descriptive by performing depth interviews with community figures. The results of this research have indicated that media literacy is a method of non-structural mitigation which is effective and in accordance with the development of the era. The implemented media are printed or social media because both media are considered relevant as the socialization media regarding the knowledge of cyclones.

Keywords: cyclone, media literacy, non-structural mitigation

\section{G OPEN ACCESS}

How to cite this article: Dina Ruslanjari, Titis Puspita Dewi, and Anisa Eka Puspitasari, (2019), "Non-Structural Mitigation Through Media Literacy on Cyclone Disaster in West Muna Regency Mitigasi Non Struktural Melalui Literasi Media Pada Bencana Angin Puting Beliung Di Kabupaten Muna Barat" in The 10th IGSSCI (International Page 146 Graduate Students and Scholars' Conference in Indonesia) NEW MEDIA AND THE CHANGING SOCIAL LANDSCAPE OF CONTEMPORARY SOCIETIES: How are new media reshaping the whole aspects of life of contemporary societies?, KnE Social Sciences, pages 146-165. DOI 10.18502/kss.v3i20.4933 


\section{ABSTRAK}

Bencana angin puting beliung merupakan bencana paling mematikan nomor dua di Indonesia setelah bencana banjir. Angin puting beliung biasanya terjadi pada saat musim peralihan atau musim pancaroba (dari musim kemarau menuju ke musim penghujan). Kabupaten Muna Barat merupakan salah satu wilayah yang mulai mengenal angin puting beliung sebagai bencana sejak tahun 2015 dimana kejadian tersebut merupakan kejadian yang paling besar yang pernah terjadi. Bencana tersebut mengakibatkan sebanyak 600 rumah rusak berat yang tersebar di tiga kecamatan yaitu Kecamatan Tiworo Utara, Kecamatan Tiworo Selatan, dan Kecamatan Tiworo Kepulauan. Kejadian tersebut disebabkan sebaran desa di tiga kecamatan tersebut pada umumnya merupakan desa terapung yang jauh dari daratan Pulau Muna.

Bencana puting beliung yang terjadi di Kabupaten Muna Barat perlu mendapatkan perhatian salah satunya melalui mitigasi non-struktural. Mitigasi non-struktural dapat berupa penyusunan perundang-undangan, penyusunan peta rawan, penysunan peta risiko, pembatasan zonasi, pendidikan, penyuluhan, dan penyadaran kepada masyarakat. Fokus penelitian ini adalah rekomendasi pelaksanaan mitigasi non-struktural dengan literasi media yang masuk di dalam penyadaran kepada masyarakat. Adapun tujuan penelitian untuk meningkatkan kesadaran serta pengetahuan masyarakat terkait bencana puting beliung. Metode penelitian yang digunakan adalah deskriptif kualitatif dengan melakukan wawancara mendalam kepada tokoh masyarakat. Hasil dari penelitian ini, literasi media merupakan metode mitigasi non-struktural yang efektif dan sesuai dengan perkembangan zaman. Media yang digunakan adalah media cetak maupun media sosial, kedua media tersebut dirasa relevan sebagai sarana sosialisasi mengenai pengetahuan angin puting beliung.

Kata Kunci: angin puting beliung, literasi media, mitigasi non-struktural

\section{Introduction}

Indonesia is a tropical climate country which tends to be humid. This condition means. the country is susceptible to the occurrence of hydro-meteorological disasters (Putuhuru, 2014). A hydro-meteorological disaster is a disaster which is associated with climate (Azis, 2008). The report by the Global Humanitarian Forum Geneva (2009) stated that climate change becomes the reason for the increasing event of a hydro-meteorological disasters because it determines the change of rain and weather 
characteristics. The increasing occurrence of hydro-meteorological disasters has not been merely caused by the change of the global climate, but also due to the errors in environmental management (Qodriyatun, 2013). Hydro-meteorological disasters consist of floods, landslides, droughts, tidal waves, and cyclones. A cyclone is one of the hydrometeorological disasters which frequently occurs. In 2018, there were 431 accounts of cyclone events out of 1,130 entire events in Indonesia (Disaster Information Database of Indonesia, 2018).

A cyclone commonly occurs during the transitional season. In the transitional season, the change from dry to rainy season occurs as well as the opposite, the weather in Indonesia is sometimes difficult to predict in these months. Cyclones mostly occur during the day and towards the night. Cyclones can be defined as a strong wind which occurs suddenly with a center, moving in a circle like a spiral until it touches the surface of the earth. The life span is very short, which only around 3-5 minutes from the start of the occurrence until it finished. Cyclone disasters are purely caused by natural factors (Harsa et al., 2011). They result from clotted and dark clouds which. are located very high or generally called as cumulonimbus. Cumulonimbus cloud causes a sudden heavy downpour, or if there is light rain, thus, the cyclone is located far from the location of the light rain (Natalyn and Permana, 2018). The area which is impacted by the occurrence of the cyclone is mostly local and the losses which emerge after the disaster can be quite massive.

Some cyclone-susceptible areas include Nusa Tenggara, Sulawesi, and Sumatera (Permadi, 2004). Some of the provinces which are frequently hit by cyclone are Southeast Sulawesi, Sulawesi Island, and eastern parts of Indonesia that mostly consist of archipelagos. Southeast Sulawesi Province has experienced 16 events of cyclones from a total of 59 disasters between 2015-2018. The Regency in Southeast Sulawesi Province where the most frequent natural disaster is cyclones ( $3 / 5$ disaster events) is West Muna Regency (Disaster Information Database of Indonesia, 2018)

Cyclone events in West Muna Regency is known as tambosisi. The local community of West Muna Regency has known cyclones as a disaster since 2015. According to the information from the Regional Disaster Management Authority (BPBD) of West Muna Regency, the cyclone at that time was the biggest disaster event to date, which heavily damaged 600 houses. The impacted areas were spread in three districts, namely North Tiworo District, South Tiworo District, and Tiworo Archipelago District. The results of the preliminary survey of this research have indicated that cyclone and tidal waves frequently occured in the archipelago areas (Bero Village, Santigi Village, Gala Village, Maginti Village, Balu Village, and Tobea Village) in October to March. The local people 
recognize these months as the west season. In this season, the condition of the local people are not merely threatened by cyclone disasters, but also by 2-3 meters tidal waves, therefore, they unable to go to the ocean for fishing. These conditions are caused by the area's geographical position which is located at the archipelago of Tiworo Bay combined with the conditions of the vulnerability and low capacity of the community; therefore, they conceive high risk towards the cyclone and tidal wave hazards.

Cyclones tends to ravage their houses and blow away their properties, moreover, the local people especially Bajo Tribe which inhabit the area of the West Muna Regency live in the middle of the sea or in the tidal land. The Bajo Tribe people who live in this area mostly work as the fisherman with unstable income; thus, their socialeconomic condition is quite concerning. This situation is increasing the vulnerability of the local people toward disasters. Due to that matter, the government needs to conduct prevention or mitigation. In line with the global paradigm, the 2015-2019 Medium Term Development Plan (RPJMN) of the Republic of Indonesia includes the internalisation of disaster risk reduction in the sustainability development framework for local and national level, disaster vulnerability subtraction, government capacity enhancement, and the society in disaster management.

The mitigation activities that can be implemented in the area are structural and non-structural. Structural mitigation is the effort to reduce vulnerability towards disaster through technical engineering of disaster-resistant buildings, while non-structural mitigation can be embodied in the form of spatial management and training to improve the capacity of the community (Law No. 24/2007 regarding Disaster Management). In this research, the author was focusing on non-structural mitigation due to the inadequate knowledge of the local people about cyclones. According to Law No.24/2007 regarding disaster management, non-structural mitigation is the mitigation which is performed through socialization, policy formulation, the training of risk map formulation, zonation, education, counseling, and emerging awareness toward the community which is unrelated to the physical development.

Non-structural mitigation toward the Bajo Tribe people was implemented through media literacy that was categorized as emerging awareness of the community. This research aimed to enhance the awareness and knowledge of the local people regarding cyclone disasters. The awareness and knowledge regarding cyclones needs to be provided for the community/local people so their capacity against disasters can be improved; therefore, it could reduce the risk of cyclone disasters. The focus of this research was recommending the implementation of non-structural mitigation through media literacy, categorized as establishing awareness within the community. This 
research has aimed to enhance the awareness and knowledge of the community related to cyclone disasters.

\section{Research Method}

The research was conducted in West Muna Regency, in which the location was taken purposively with the criteria of an island frequently hit by cyclone disasters. The selected sample was the Bajo Tribes people who live on the small inhabited island. West Muna Regency has 12 (twelve) villages; there are six populated villages namely Tiga Village, Bero Village, Mandike Village, Tasipi Village, and Katela Village. The characteristics of houses in the floating village are either stage or non-stage type, based on wood, with sago palm leaves as the roof material. One house to another is connected by footbridges. Tiworo bay is the fishing ground area; therefore, most of the local people work as fishermen.

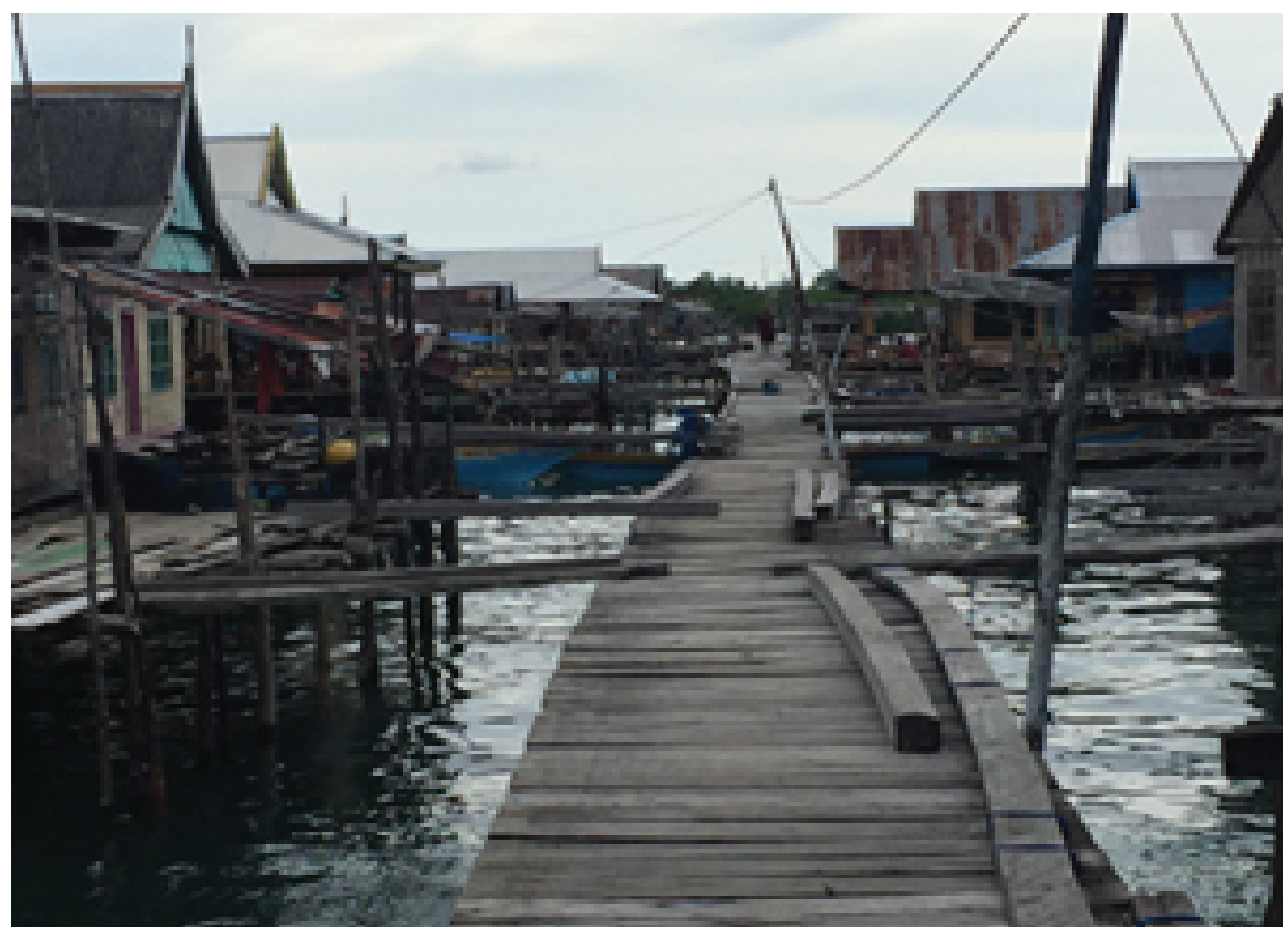

Figure 1: The housing conditions in one of the studied villages.

In the research of "Non-Structural Mitigation through Media Literacy on Cyclone Disaster in West Muna Regency", the researcher used a qualitative descriptive method 
through in-depth interviews with community figures in the high-susceptible areas. The indepth interview technique used was snowball sampling. This research aimed to enhance the awareness as well as the knowledge of local people regarding cyclone disaster. 


\section{Result and Discussion}

\subsection{Vulnerability}

Based on the objective targets of the Sendai Framework for Disaster Risk Reduction (SFDRR), planning and controlling the potential risks is integrated by increasing capacity, reducing vulnerability, increasing resilience and improving the preparedness of all stakeholders (UNISDR, 2015; BNPB, 2015). According to UNISDR (2009) Disaster risk reduction is a conceptual framework of elements that contain the possibility of reducing disaster vulnerability, preventing, mitigating, and increasing preparedness efforts from disaster impacts and threats for sustainable development.

In disaster risk reduction, community capacity has a very important role. The low capacity of the community will also reduce disaster risk reduction. It will have an impact on the many casualties from when a disaster occurs. Likewise, vulnerability greatly influences people's safety from the threat of disaster. Vulnerability is strongly influenced by physical vulnerability and of course the environment in which one lives.

Vulnerability does not occur naturally but is related to the human dimension of disaster which is the result of the linkages of economic, social, cultural, institutional factors, politics that contributing to human life and the environment in which they live. As Twigg (2004) stated, vulnerability always changes dynamically every time (Thywissen, 2006) depending on the condition of the community's vulnerability to certain hazards.

UNISDR (2004) divides vulnerabilities into four types, namely physical, social, economic and environmental. Each type of vulnerability has related characteristics from one another, whether it comes from physical, social, economic and environmental factors. The level of vulnerability is one of the factors that influence the occurrence of a disaster, because a new disaster will occur if the danger exists in vulnerable conditions. According to Vogel and O'Brien (2004); Lummen and Yamada (2014), vulnerability has multidimensional aspects (such as: physical, social, economic, environmental, institutional and human factors determining vulnerability); vulnerability can be measured at the level of individuals, households, communities through to the state level, because each location requires its own approach. Vulnerability is related to risk elements (elements at risk), which include all objects; people, animals, activities and processes that can be adversely affected by harmful phenomena in certain areas, both directly or indirectly (Van Westen, 2011).

Mitigation effort can be conducted in the community if we understand the existing vulnerability and capacity; therefore, the best efforts can be formulated in reducing the 
risk of cyclone disasters. The physical vulnerability of the community is the dependent variable obtained from 3 independent variables. The independent variables consist of the age of the building, material, and structure of the house. The ages of houses in this study consist of; the low-vulnerability class, in which the age of the building ranges from 0 - 12 years; medium-vulnerability class in which the range is 13-24 years; and high-vulnerability class which includes approximately 25 years of the building age. The results of the research analysis of physical vulnerability with weights derived from AHP analysis can be seen in Table 1.

TABLE 1: Physical Vulnerability.

\begin{tabular}{l|l|c|c|c|c|c|} 
No. & Village & $\begin{array}{c}\text { The Age } \\
\text { of } \\
\text { Building } \\
\mathbf{( 2 0 , 6 9 \% )}\end{array}$ & $\begin{array}{c}\text { Building } \\
\text { Material } \\
\mathbf{( 2 0 , 5 1 \% )}\end{array}$ & $\begin{array}{c}\text { Material } \\
\text { Structure } \\
\mathbf{( 5 8 , 8 0 \% )}\end{array}$ & Score & Classification \\
\hline 1 & Tiga & 3 & 3 & 3 & 3 & $\mathrm{H}$ \\
\hline 2 & Bero & 2 & 3 & 3 & 2,67 & $\mathrm{M}$ \\
\hline 3 & Mandike & 1 & 3 & 3 & 2,33 & $\mathrm{M}$ \\
\hline 4 & Tasipi & 3 & 3 & 3 & 3 & $\mathrm{H}$ \\
\hline 5 & Katela & 3 & 3 & 3 & 3 & $\mathrm{H}$ \\
\hline
\end{tabular}

Bakornas PB (2007) divided physical vulnerability into basic infrastructure, construction, and buildings. The traditional house of the Bajo Tribe is square or rectangular. The roof is shaped like a pyramid which is formed by thatch or zinc. The walls and floors of the house are made of wooden planks, but there are still many Bajo houses that use silar leaves, the sago nan palm fronds as the walls.

Bajo tribal houses are made similar to a stage; the main material used is wood as the foundation and the body of the house. They use local wood such as ironwood, gravel, togoulu, kalakka, and manjarite, which are round formed that still has skin, measuring between $15-25 \mathrm{~cm}$ in diameter. The longer the life of the building, the more vulnerable it will be, because the wooden material becomes weathered.

Building material comes from wood, which certainly has a high vulnerability during the hazard of a cyclone. Wood material is light, so when it is exposed to $40-50 \mathrm{~km} / \mathrm{hour}$ wind speed in a very short duration, a maximum of 5 minutes of that wind will be able to lift a house, for the building does not have a strong structure (Harsa et al., 2011).

The structure of the house building is the highest factor of physical vulnerability. The structure is the parts that construct buildings such as foundations, sloop, walls, columns, rings, trestles, and roofs. The role of the building structure is to withstand the building load from the upper part of the building to the lower part of the building, then spread it to 


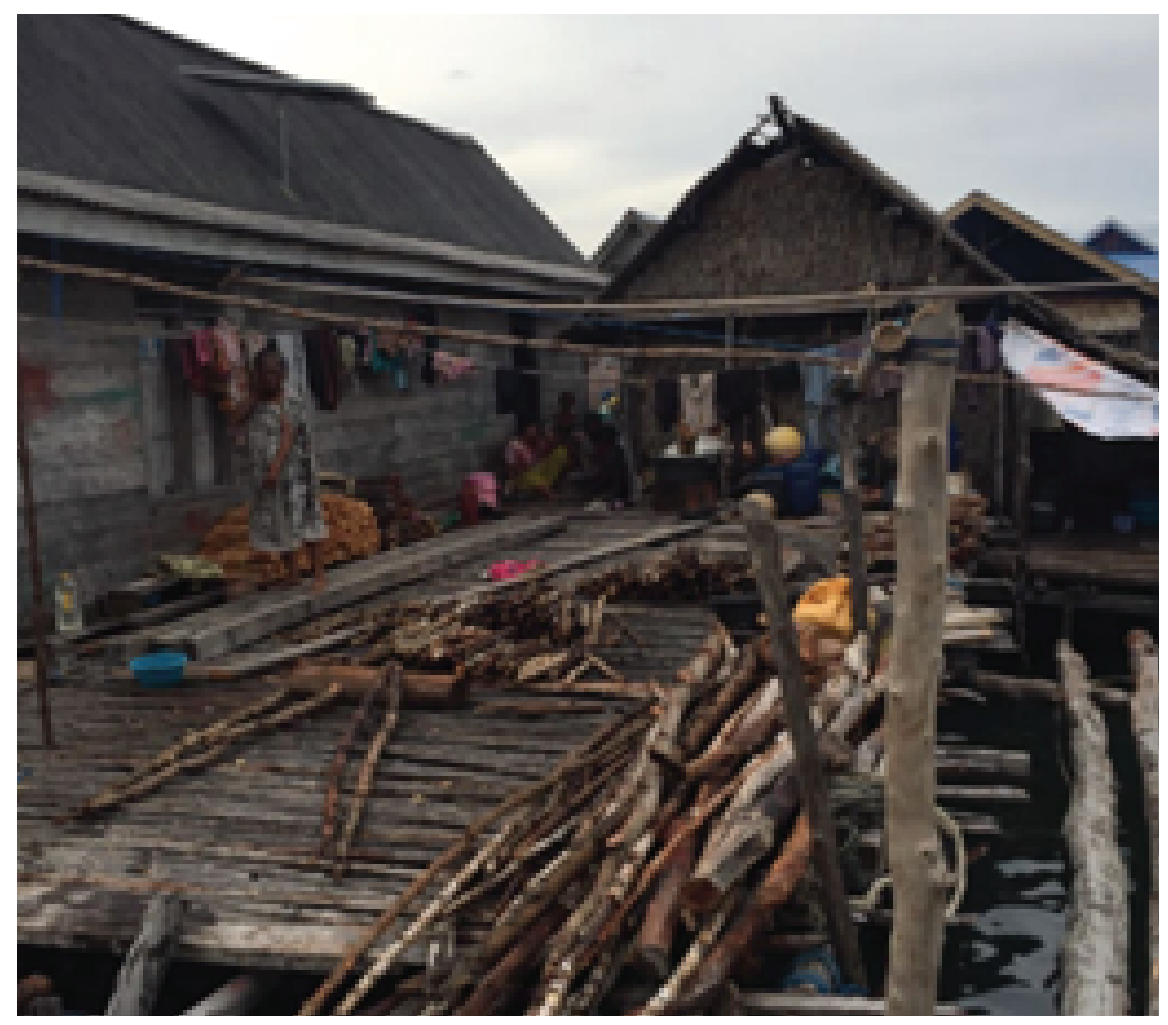

Figure 2: Traditional House of Bajo Tribe. (Source: Researchers, 2018)

the ground, so that it can bear the gravity and building loads (https://blog-mue.blogspot. com/2016/03/definisi-struktur-dan-kontruksi.html, retrieved on October 22, 2018).

The second component of vulnerability is the economic vulnerability. Economic vulnerability is the dependent variable acquired through four dependent variables. The dependent variables consist of the type of livelihood, last education, house ownership, and monthly average income. The research instrument was a questionnaire applied to obtain data regarding the economic vulnerability of the community.

The livelihood types in this research consist of low-vulnerability class namely civil apparatus/teacher; medium-vulnerability class namely fisherman and owning boats; high-vulnerability class namely fisherman with non-ownership of boat, and people with odd jobs. The results of the research analysis of economic vulnerability with weights derived from AHP analysis can be seen in Table 2.

Bakornas PB, (2007) stated that one of the vulnerability factors is economic vulnerability, which consists of livelihood, house ownership, and family income. The average income of the community is low, under Rp. 1,450,000/month. The local fishermen only depend on the traditional equipment for fishing such as nets and a tool similar to an arrow. 
TABLE 2: Economic Vulnerability.

\begin{tabular}{l|l|c|c|c|c|c|} 
No. & Village & $\begin{array}{c}\text { Type of } \\
\text { Job } \\
(\mathbf{4 1 , 5 7 \% )}\end{array}$ & $\begin{array}{c}\text { Family Income } \\
\mathbf{( 2 6 , 2 8 )}\end{array}$ & $\begin{array}{c}\text { Building } \\
\text { Ownership } \\
\mathbf{( 3 2 , 1 5 \% )}\end{array}$ & Score & Classification \\
\hline 1 & Tiga & 2 & 3 & 1 & 2 & $\mathrm{M}$ \\
\hline 2 & Bero & 2 & 3 & 1 & 2 & $\mathrm{M}$ \\
\hline 3 & Mandike & 2 & 2 & 1 & 1,67 & $\mathrm{~L}$ \\
\hline 4 & Tasipi & 2 & 3 & 1 & 2 & $\mathrm{M}$ \\
\hline 5 & Katela & 2 & 3 & 1 & 2 & $\mathrm{M}$ \\
\hline
\end{tabular}

The type of livelihood of the local community is fishermen, and they havewooden boats, even though the boats are very simple. The boat is also used for transportation to other villages, or the main island in the city of Muna Barat Regency. In addition, children go to schools located on the other islands by boat. The house is self-owned with the exiguous condition which have the possibility to be destroyed when big cyclones happen.

The third component of vulnerability is social vulnerability. Social vulnerability of the community is the dependent variable which is acquired through six independent variables. The independent variables consist of the number of family member, the residential period, the number of people with a vulnerable age, the number of women in the family, the number of disabled individuals in the family, and the number of family dependent. The research instrument was a questionnaire used to obtain data regarding the social vulnerability of the community.

The number of family members in this research consist of low-vulnerability class namely $<2$ individuals per household; medium-vulnerability class namely 2-3 individuals per household, and high-vulnerability class namely $>3$ individuals per household. The results of the research analysis on social vulnerability with weights derived from AHP analysis can be seen in Table 3.

There are people with disabilities in Mandike Village and Tasipi Village. This condition happens because they dive to catch the fish in the night only using the flashlight and no safety equipment. As the impact of that minimum safety, their hands and feet are attacked by the sharks.

The number of disabled individuals is the highest factor in social vulnerability, although there are no disabled people from the tested research sample. There are only a small number of housewives in the islands who can help the work of their husbands because they have to take care of their children, while some of them create nets. The 
TABLE 3: Social Vulnerability.

\begin{tabular}{|c|c|c|c|c|c|c|c|c|c|c|}
\hline No. & Village & $\begin{array}{l}\text { Domi- } \\
\text { cile } \\
\text { Period } \\
(5,74 \%)\end{array}$ & $\begin{array}{c}\text { Total of } \\
\text { Family } \\
\text { Mem- } \\
\text { bers } \\
(9,56 \%)\end{array}$ & $\begin{array}{c}\text { Total of } \\
\text { Family } \\
\text { Depen- } \\
\text { dents } \\
(8,57 \%)\end{array}$ & $\begin{array}{c}\text { Number } \\
\text { of Dis- } \\
\text { abilities } \\
(24,47 \%)\end{array}$ & $\begin{array}{c}\text { Number } \\
\text { of } \\
\text { Vulnera- } \\
\text { bilities } \\
(22,94 \%)\end{array}$ & $\begin{array}{c}\text { Number } \\
\text { of } \\
\text { Females } \\
(11,64 \%)\end{array}$ & $\begin{array}{l}\text { Populat- } \\
\text { ion } \\
\text { Density } \\
(17,08)\end{array}$ & Score & $\begin{array}{l}\text { Classifi- } \\
\text { cation }\end{array}$ \\
\hline 1 & Tiga & 3 & 3 & 2 & 1 & 1 & 2 & 2 & 1,86 & L \\
\hline 2 & Bero & 3 & 3 & 3 & 1 & 1 & 2 & 2 & 2 & M \\
\hline 3 & Mandike & 3 & 3 & 2 & 1 & 1 & 1 & 2 & 1,71 & L \\
\hline 4 & Tasipi & 3 & 3 & 3 & 1 & 1 & 2 & 2 & 1,86 & L \\
\hline 5 & Katela & 3 & 3 & 2 & 1 & 1 & 2 & 2 & 1,86 & L \\
\hline \multicolumn{11}{|c|}{ Source: Data Analysis (2018) } \\
\hline & $y=$ & & 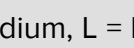 & & & & & & & \\
\hline
\end{tabular}

rest of them peel the fish, take out the fishbone, and dry fish. The population density in a region determines the vulnerability condition if a disaster occurs because it is related to the number of fatalities.

A total vulnerability is the combination of physical, economic and social vulnerabilities that can be seen in Table 4. This study does not calculate environmental vulnerability, due to its definition based on UNISDR, 2004. Environmental vulnerability is measured by access to health facilities, road networks and the availability of clean water. These three variables have the same results, which all conceive high vulnerabilities. This result is based on the unavailability of road networks where there are only wooden bridges that connect one house to another, the lack of clean water, thus, that people must provide it by themselves, and there is no access to health facilities.

TABLE 4: Total of Vulnerability Score.

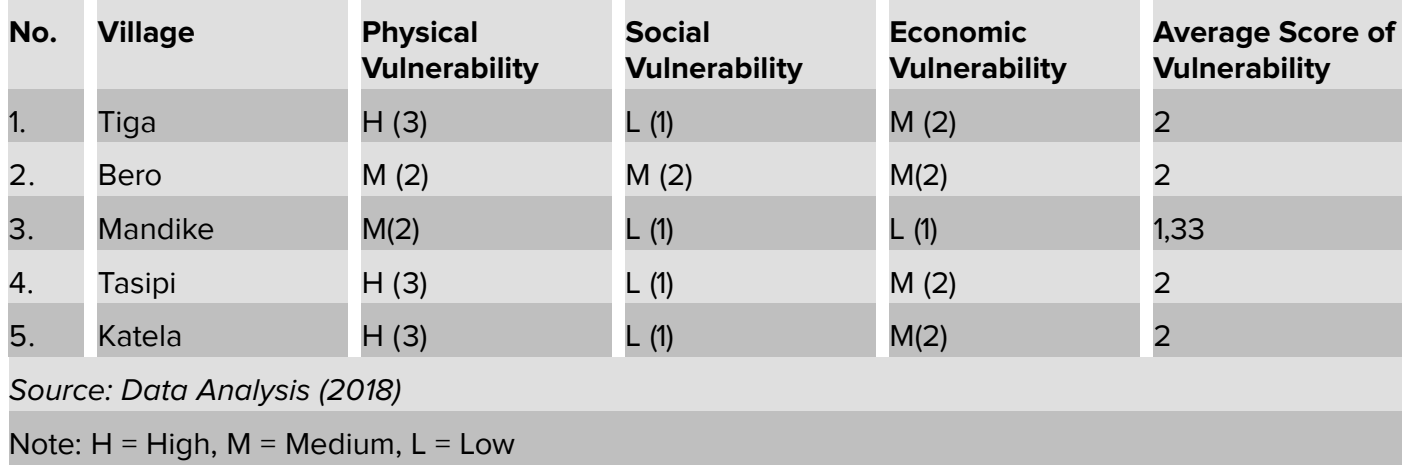

\subsection{Community capacity}

The level of community capacity is acquired through the implementation of assessments on awareness variables consisting of knowledge indicators, responses to the cyclone, 
perception, and information. Preparedness assessment variables consist of preparation before the occurrence of a cyclone, membership in community organizations, and participation in disaster training. Community capacity analysis was implemented to obtain a total capacity index value as the sum of awareness and preparedness indices.

Awareness assessment variables in this study consist of knowledge indicators, responses to the cyclones, perceptions, and information made in several questions with the answer choices of No (1) - showing low awareness; Uncertain (2) - providing moderate awareness, and Yes (3) - presenting high awareness. The results of the research questionnaire analysis on the variables of awareness assessment can be seen in Table 5.

TABLE 5: Awareness Assessment.

\begin{tabular}{|c|c|c|c|c|c|}
\hline No. & Village & Knowledge & Response & Perception & Information \\
\hline 1. & Tiga Village & $\begin{array}{l}\text { Low - } 1 \text { (do not } \\
\text { have enough } \\
\text { knowledge about } \\
\text { cyclone disasters) }\end{array}$ & $\begin{array}{l}\text { High }-3 \\
\text { (conducting some } \\
\text { responses while } \\
\text { the cyclone } \\
\text { occurs) }\end{array}$ & $\begin{array}{l}\text { High - } 3 \text { (have } \\
\text { perception toward } \\
\text { cyclone disaster) }\end{array}$ & $\begin{array}{l}\text { Low - } 1 \text { (The } \\
\text { unavailability of } \\
\text { cyclone } \\
\text { information) }\end{array}$ \\
\hline 2. & Bero Village & $\begin{array}{l}\text { Low - } 1 \text { (do not } \\
\text { have enough } \\
\text { knowledge about } \\
\text { cyclone disasters) }\end{array}$ & $\begin{array}{l}\text { High - } 3 \\
\text { conducting some } \\
\text { responses while } \\
\text { the cyclone } \\
\text { occurs) }\end{array}$ & $\begin{array}{l}\text { High - } 3 \text { (have } \\
\text { perception toward } \\
\text { cyclone disaster) }\end{array}$ & $\begin{array}{l}\text { Low }-1 \text { (The } \\
\text { unavailability of } \\
\text { cyclone } \\
\text { information) }\end{array}$ \\
\hline 3. & Mandike Village & $\begin{array}{l}\text { Low - } 1 \text { (do not } \\
\text { have enough } \\
\text { knowledge about } \\
\text { cyclone disasters) }\end{array}$ & $\begin{array}{l}\text { High - } 3 \\
\text { (conducting some } \\
\text { responses while } \\
\text { the cyclone } \\
\text { occurs) }\end{array}$ & $\begin{array}{l}\text { High - } 3 \text { (have } \\
\text { perception toward } \\
\text { cyclone disaster) }\end{array}$ & $\begin{array}{l}\text { Low - } 1 \text { (The } \\
\text { unavailability of } \\
\text { cyclone } \\
\text { information) }\end{array}$ \\
\hline 4. & Tasipi Village & $\begin{array}{l}\text { Low - } 1 \text { (do not } \\
\text { have enough } \\
\text { knowledge about } \\
\text { cyclone disasters) }\end{array}$ & $\begin{array}{l}\text { High - } 3 \\
\text { (conducting some } \\
\text { responses while } \\
\text { the cyclone } \\
\text { occurs) }\end{array}$ & $\begin{array}{l}\text { High - } 3 \text { (have } \\
\text { perception toward } \\
\text { cyclone disaster) }\end{array}$ & $\begin{array}{l}\text { Low - } 1 \text { (The } \\
\text { unavailability of } \\
\text { cyclone } \\
\text { information) }\end{array}$ \\
\hline 5. & Katela Vilage & $\begin{array}{l}\text { Low - } 1 \text { (do not } \\
\text { have enough } \\
\text { knowledge about } \\
\text { cyclone disasters) }\end{array}$ & $\begin{array}{l}\text { High }-3 \\
\text { (conducting some } \\
\text { responses while } \\
\text { the cyclone } \\
\text { occurs) }\end{array}$ & $\begin{array}{l}\text { High - } 3 \text { (have } \\
\text { perception toward } \\
\text { cyclone disaster) }\end{array}$ & $\begin{array}{l}\text { Low - } 1 \text { (The } \\
\text { unavailability of } \\
\text { cyclone } \\
\text { information) }\end{array}$ \\
\hline \multicolumn{6}{|c|}{ Source: Data Analysis (2018) } \\
\hline
\end{tabular}

The results of the questionnaire related to community capacity variables were analyzed, and then the variables for assessment questionnaire were arranged which is applied as the input for weighting.

Based on the AHP calculation, the researcher then classifies the total awareness capacity based on the independent variables to form Table 6. The indicators include knowledge, responses, perception, and information. 
TABLE 6: Classification of Total Awareness Capacity.

\begin{tabular}{|l|c|c|}
\hline No. & Village & $\begin{array}{c}\text { Knowledge } \\
\text { (31,67 \%) }\end{array}$ \\
\hline 1. & Tiga & 1 \\
\hline 2. & Bero & 1 \\
\hline 3. & Mandike & 1 \\
\hline 4. & Tasipi & 1 \\
\hline 5. & Katela & 1 \\
\hline
\end{tabular}

\begin{tabular}{|c|}
$\begin{array}{c}\text { Responses } \\
(14,75 \%)\end{array}$ \\
\hline 3 \\
3 \\
\hline 3 \\
3 \\
\hline 3 \\
\hline
\end{tabular}

Perception
(19,72\%)
3
3
3
3
3

\begin{tabular}{c}
$\begin{array}{c}\text { Information } \\
(33,87 \%)\end{array}$ \\
1 \\
1 \\
\hline 1 \\
\hline 1 \\
\hline 1 \\
\hline
\end{tabular}

\begin{tabular}{|c|}
\hline Score \\
\hline 2 \\
\hline 2 \\
\hline 2 \\
\hline 2 \\
\hline 2 \\
\hline
\end{tabular}

Class M

$\mathrm{M}$ M M $M$

Source: Data Analysis (2018)

Note: $\mathrm{H}=$ High, $M=$ Medium, $L=$ Low

Preparedness assessment variables in this study consist of: indicators of preparation before the occurrence of a cyclone, membership in community organizations, and participation in disaster training which was made in several questions with the choice of answers of No (1) - showing low preparedness; Uncertain (2) - providing moderate preparedness; and Yes (3) - presenting high preparedness.

The results of the research questionnaire analysis on preparedness assessment variables can be seen in Table 7. The capacity of the community is carried out to obtain total capacity index value as the sum of the awareness and preparedness indices.

TABLE 7: Community Preparedness Assessment.

\begin{tabular}{|c|c|c|c|c|}
\hline No. & Village & $\begin{array}{l}\text { Preparedness Before } \\
\text { the Cyclone Occurs }\end{array}$ & $\begin{array}{l}\text { Membership in } \\
\text { Community } \\
\text { Organization }\end{array}$ & $\begin{array}{l}\text { Participation in } \\
\text { Disaster Training }\end{array}$ \\
\hline 1. & Tiga & $\begin{array}{l}\text { Low - } 1 \text { (No } \\
\text { preparedness before } \\
\text { the disaster happens) }\end{array}$ & $\begin{array}{l}\text { Medium - } 1 \text { (Not in a } \\
\text { Community Related to } \\
\text { Disaster) }\end{array}$ & $\begin{array}{l}\text { Low - } 1 \text { (Not often } \\
\text { involved in disaster } \\
\text { training) }\end{array}$ \\
\hline 2. & Bero & $\begin{array}{l}\text { Low - } 1 \text { (No } \\
\text { preparedness before } \\
\text { the disaster happens) }\end{array}$ & $\begin{array}{l}\text { Medium - } 1 \text { (Not in a } \\
\text { Community Related to } \\
\text { Disaster) }\end{array}$ & $\begin{array}{l}\text { Low - } 1 \text { (Not often } \\
\text { involved in disaster } \\
\text { training) }\end{array}$ \\
\hline 3. & Mandike & $\begin{array}{l}\text { Low - } 1 \text { (No } \\
\text { preparedness before } \\
\text { the disaster happens) }\end{array}$ & $\begin{array}{l}\text { Medium - } 1 \text { (Not in a } \\
\text { Community Related to } \\
\text { Disaster) }\end{array}$ & $\begin{array}{l}\text { Low - } 1 \text { (Not often } \\
\text { involved in disaster } \\
\text { training) }\end{array}$ \\
\hline 4. & Tasipi & $\begin{array}{l}\text { Low - } 1 \text { (No } \\
\text { preparedness before } \\
\text { the disaster happens) }\end{array}$ & $\begin{array}{l}\text { Medium - } 1 \text { (Not in a } \\
\text { Community Related to } \\
\text { Disaster) }\end{array}$ & $\begin{array}{l}\text { Low - } 1 \text { (Not often } \\
\text { involved in disaster } \\
\text { training) }\end{array}$ \\
\hline 5. & Katela & $\begin{array}{l}\text { Low - } 1 \text { (No } \\
\text { preparedness before } \\
\text { the disaster happens) }\end{array}$ & $\begin{array}{l}\text { Medium - } 1 \text { (Not in a } \\
\text { Community Related to } \\
\text { Disaster) }\end{array}$ & $\begin{array}{l}\text { Low - } 1 \text { (Not often } \\
\text { involved in disaster } \\
\text { training) }\end{array}$ \\
\hline
\end{tabular}

The sum of awareness and preparedness namely the community capacity index is shown in Table 8. 
TABLE 8: Community Capacity

\begin{tabular}{l|c|c|c|c|c|} 
No. & Village & $\begin{array}{c}\text { Awareness } \\
\text { Assessment } \\
\text { Variable }\end{array}$ & $\begin{array}{c}\text { Preparedness } \\
\text { Assessment } \\
\text { Variable }\end{array}$ & $\begin{array}{c}\text { Total of } \\
\text { Assessment } \\
\text { Variable }\end{array}$ & $\begin{array}{c}\text { Average of } \\
\text { Community } \\
\text { Capacity }\end{array}$ \\
\hline 1. & Tiga & 2 & 1 & 3 & 1,5 \\
\hline 2. & Bero & 2 & 1 & 3 & 1,5 \\
\hline 3. & Mandike & 2 & 1 & 3 & 1,5 \\
\hline $4 . \quad$ & Tasipi & 2 & 1 & 3 & 1,5 \\
\hline 5. & Katela & 2 & 1 & 3 & 1,5 \\
\hline Source: Data Analysis (2018) & & & & \\
\hline
\end{tabular}

Based on the Typology of Community Vulnerability and Capacity in Cyclone Disaster Preparedness (Muta'ali, 2014 modified by the researcher), the researcher concludes the analysis of community preparedness in Table 9.

TABLE 9: Total of Community Preparedness.

\begin{tabular}{l|c|c|c|} 
No. & Village & $\begin{array}{c}\text { Vulnerability } \\
\text { Average }\end{array}$ & $\begin{array}{c}\text { Total Variable Average of } \\
\text { Community Capacity }\end{array}$ \\
\hline 1. & Tiga & 2 & 1,5 \\
\hline 2. & Bero & 2 & 1,5 \\
\hline 3. & Mandike & 1,33 & 1,5 \\
\hline 4. & Tasipi & 2 & 1,5 \\
\hline 5. & Katela & 2 & 1,5 \\
Source: Data Analysis (2018) & \\
Note: H = High, M = Medium, L = Low
\end{tabular}

Furthermore, the typology is made in Table 10 as the function combining the results of Table 4 and Table 9.

TABLE 10: Typology of Community Vulnerability and Capacity.

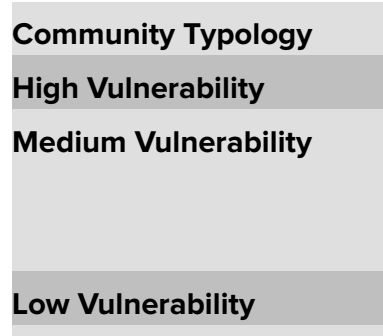

\begin{tabular}{c} 
Low Capacity \\
\hline 1 \\
\hline 4 \\
\hline 7 \\
\hline
\end{tabular}


Source: Data Analysis, 2018

The results that have been performed in this study indicate that the villages in West Muna Regency consist of 2 types as follows:

1. Tiga, Bero, Tasipi, and Katela Villages have medium vulnerability whilst Mandike Village has low vulnerability, 
2. Tiga, Bero, Tasipi, Mandika, and Katela Villages are classified as having medium capacity level.

\subsection{Media literacy as non-structural mitigation}

The occurance of cyclone disasters in West Muna Regency requires attentions in which one way is through non-structural mitigation. Non-structural mitigation can be embodied in the form of law formulation, vulnerability map formulation, risk map formulation, zonation, education, counseling, and emerging awareness toward the community. In reference to the previous quantitative analysis, Table 10 indicates that the typology of the community in Tiga, Bero, Tasipi, and Katela Villages are categorized in medium class both in terms of vulnerability and capacity. However, Mandike Village is categorized as having moderate capacity and low vulnerability. The conclusion in which the vulnerability level is low and the capacity is moderate does not reduce the urgency of non-structural mitigation. The community is highly vulnerable, especially in the context of economic vulnerability on the point of the level of last education consisting of three scales (no education, not graduated or graduated from elementary school). Low levels of education tends to be parallel with the low capacity, especially on the point of knowledge and information regarding disaster with a scale of 1.

According to informant Ant (51 years old/not graduate from elementary school), his knowledge about cyclons was obtained through life experiences. According to $\mathrm{Nel}$ (47 years old/not graduate from elementary school), the information about the disaster was often obtained from the smartphone of his children. The son of Nel (23 years old/undergraduate student in Makassar) was frequently informing Nel about the weather prediction which were acquired through the website of Meteorological, Climatological, and Geophysical Agency (BMKG). If the son of informant Nel is studying at the University in Makassar, Nel relies on his instinct and experiences obtained during his time at sea.

One of the forms of non-structural mitigation is by creating regional level law formulation. According to informant $\mathrm{H}$. Rid (60 years old/high school graduate) who works as an honorary employee in the regency, he stated that he never heard of the formulation of law regarding disaster especially cyclones which frequently hit his area. Another form such as the arrangement/formulation of risk map and zonation has never been once socialized or implemented by the related institution including the BPBD of West Muna Regency according to informant LD U (77 years old/not graduate from elementary school). Informant LD $U$ as the community figure in Katela Village perceives that the 
regional government has been moving less actively in implementing the mitigation or prevention related to cyclone disasters.

The next forms of non-structural mitigation which include education, counseling, and emerging awareness toward community have yet to be implemented in the five research location villages according to five informants, therefore, the results of questionnaire assessment and AHP of capacity especially on the points of knowledge and information have a scale of 1 (low). One of the issues realized by the five informants was the difficulty of access toward their villages (could only be done through boat). During the west season, some of the big boats owned by fishermen who are also the middlemen cannot be operated, therefore, the fulfillment of life necessities, even the access of information, could become difficult.

On the contrary with structural mitigation (the effort to reduce vulnerability toward disaster through technical engineering of disaster-resilient buildings), according to the five informants, BPBD of West Muna Regency has socialized its special attention toward the roof of buildings. There was a recommendation in which the houses with nonpermanent roof have to be avoided during the rain and windy weather because the roofs could be easily thrown off during the heavy wind (Rosdiana, 2013). The recommendation from central government to BPDB regarding the increasing threat/hazard of disaster has demanded the mitigation efforts and awareness to reduce the risk of disaster impacts to not merely implemented in a whole and comprehensive manner toward the entire area (Octaviyani, 2019).

In the future, the disaster mitigation conducted by the BPBD of West Muna Regency, especially the efforts associated with cyclones, should embrace the disaster literacy model.

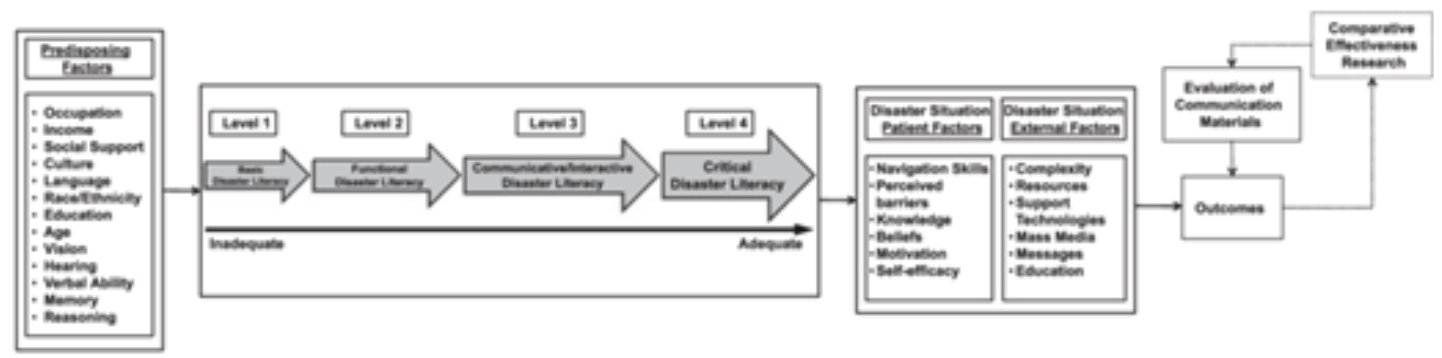

Figure 3: Disaster Literacy Model (Brown, et al, 2014).

The explanations regarding disaster literacy model are divided into four phases, such as (Muktaf, 2017): 
1. Phase 1 is the literacy initial phase. Individuals or the community are able to read and understand the instructions about disaster mitigation and preparedness. At this level, the capacity of the community tends still be at a low level but they have been willingly following the instructions regarding the messages of disaster preparedness, disaster responses, and recovery. If reviewed from the conditions in the five research locations, thus, it can be assured that the community/local people are able to undergo this phase because based of non-education experienced, the community has learned to understand the sign of the occurrence of disaster as well as giving rapid responses (indicated by the scale of 3 on the awareness assessment in the response point).

2. Phase 2 is the comprehensive skills associated with disaster information which is proved by following the recommendations and instructions. Individually, at this phase, the ability in processing information is still lacking but considered as adequately important as the asset in facing disasters that might occur suddenly. The community/local people in the research location were able to pass this phase, although, not all of them were able to use the information technology contained with disaster mitigation of cyclone. The young generation (youths) becomes the main focus in accelerating the improvement of the comprehension ability/skill.

3. Phase 3 is the motivation and confidence of individuals to be pro-active. At this level, the message can be received properly. The message can be modified or improved in accordance with familiar things. The message can be different based on the needs of individuals or the community. The important point at this phase is on the BPBD of West Muna Regency in which this institution should be able to include the local wisdom such as terminologies or local language to simplify the understanding.

4. Phase 4 is the further involvement of individuals. Individuals already understand broader information and circumstances, especially when related to the obstacles in social and environmental safeties. This phase will surely improve the scale of 1 into three on community capacity assessment.

In the time the media technology has reached digital level, thus, the variation in communicating the mitigation of the area susceptible to cyclone disaster should change as well (Priyowidodo and Luik, 2013). In principle, the idea development such as a website or the provisions of early warning information of extreme weather will be very good when accompanied by socialization, counseling, and mass training from the related institution (Rosdiana, 2013). 


\section{Conclusion}

Non-structural mitigation through media literacy is categorized in emerging awareness within the community as well as within the institution regarding the importance of prevention before the occurrence of disaster. The non-structural mitigation can be properly implemented if there is preparation by the institution to prepare the material as well as running the literacy projects for the community on a large scale. This effort will surely be able to improve the capacity and reduce the vulnerability of the community toward cyclone disaster.

\section{Acknowledgement}

Thank you to the Graduate School, Universitas Gadjah Mada through the Competitive Research Grant 2018 who have funded the conduct of research of Vulnerability Studies and The Capacity of Bajo Tribal Communities in Preparedness to Cope with Tornadoes (The Case of Muna Barat District).

\section{References}

[1] Anonim, 2016. Definisi Struktur dan Konstruksi Bangunan Terlengkap. Retrieved on October 22, 2018. <https://blog-mue.blogspot.com/2016/03/definisi-struktur-dankontruksi.html>

[2] Aziz, Muhammad Nashrul. 2018. Pengertian, Jenis, dan Macam-macam Bencana Alam Beserta Contoh Gambarnya. Retrieved on October 7, 2018. < https://pasberita. com/pengertian-macam-macam-bencana-alam/>

[3] BAKORNAS PB. 2007. Pengenalan Karakteristik Bencana dan Upaya Mitigasinya di Indonesia. Jakarta: Direktorat Mitigasi Badan Koordinasi Nasional Penanganan Bencana (BAKORNAS PB).

[4] Data Informasi Bencana Indonesia. 2018. Bencana Alam di Indonesia Tahun 2018 s/d 2018. Retrieved at October 7, 2018. <http://bnpb.cloud/dibi/grafik1a>

[5] _ 2018. Bencana Alam di Indonesia Tahun 2015 s/d 2018. Retrieved on December 12, 2018. < http://bnpb.cloud/dibi/grafik1a>

[6] Global Humanitarian Forum Geneva. 2009. Human Impact Report Climate Change - The Anatomy of a Silent Crisis. Geneva: Global Humanitarian Forum.

[7] Harsa, Hastuadi; Linarka, Utoyo Ajie; Kurniawan, Roni; dan Noviati, Sri. 2011. Pemanfaatan SATAID untuk Analisa Banjir dan Angin Puting Beliung: Studi Kasus 
Jakarta dan Yogyakarta. Jurnal Meteorologi dan Geofisika 12 (2): 197 - 205.

[8] Lummen, N. S., \& Yamada, F. 2014. Implementation of an Integrated Vulnerability and Risk Assessment Model. Natural Hazards, 73(2), 1085-1117.

[9] Muktaf, Zein Muffarih. 2017. Studi Literasi Bencana dalam Perspektif IImu Komunikasi. Retrieved on December 13, 2018. <http://repository.umy.ac.id/bitstream/handle/123456789/14605/

Studi\{\%\}2OLiterasi\{\%\}20Bencana\{\%\}20dalam\{\%\}20Perspektif\{\%\}20Komunikasi\{\%\}2Oreposito pdf? sequence $=1 \&$ isAllowed $=\mathrm{y}>$

[10] Muta'ali. Luthfi. 2014. Perencanaan Pengembangan Wilayah Berbasis Pengurangan Risiko Bencana. Yogyakarta: BPFG Universitas Gadjah Mada.

[11] Natalyn, Ezra dan Permana, Ridho. 2018. Ketahuilah Tanda-Tanda Bakal Muncul Angin Putting Beliung. Retrieved on December 13, 2018. < https: //www.msn.com/id-id/berita/cuaca/ketahui-tanda-tanda-bakal-muncul-anginputing-beliung/ar-BBQAOdG>

[12] Octaviyani, Putri Rosmalia. 2019. Tingkatkan Efektivitas Mitigasi Bencana Daerah. Retrieved on January 14, 2019. <http://mediaindonesia.com/read/detail/210337tingkatkan-efektivitas-mitigasi-bencana-daerah>

[13] Permadi, Arief. 2014. Ini Dia, Daerah Rawan Angin Puting Beliung di Indonesia. Retrieved on October 7, 2018. <http://jabar.tribunnews.com/2014/12/18/ini-diadaerah-rawan-angin-puting-beliung-di-indonesia>

[14] Priyowidodo, Gatut dan Luik, Jandy E. 2013. Literasi Mitigasi Bencana Tsunami untuk Masyarakat Pesisir di Kabupaten Pacitan Jawa Timur. Jurnal Ekotrans 13 (1): 47 - 61.

[15] Putuhuru, Ferad. 2014. Mitigasi Bencana dan Penginderaan Jauh. Yogyakarta: Graha IImu.

[16] Qodriyatun, Sri Nurhayati. 2013. Bencana Hidrometrologi dan Upaya Adaptasi Perubahan Iklim. Info Singkat 5 (10): 9 - 12.

[17] Rosdiana, Fahmi. 2013. Puting Beliung, Bencana Regional dengan Sebaran Nasional. Jurnal Mitigasi Bencana Oktober 2013.

[18] Medium Term Development Plan (RPJMN) of the Republic of Indonesia 2015-2019.

[19] Thywissen. 2006. Components of Risk, A Comparative Glossary. Bonn: United Nations University Institute for Environment and Human Security.

[20] Twigg, J. 2004. Disaster Risk Reduction: Mitigation and Preparedness in Development and Emergency Programming, Good Practice Review 9. Humanitarian Practice Network (HPN), London: ODI

[21] Undang-Undang No. 24 tahun 2007 Tentang Penanggulangan Bencana 
[22] UNISDR. 2004. Living with Risk: A Global Review of Disaster Reduction Initiatives. New York: United Nations International Strategy for Disaster Reduction Secretariat (UNISDR).

[23] Van Westen, C. J., Alkema, D., Damen, M. C., Kerle, N., \& Kingma, N. C. 2011. MultiHazard Risk Assessment. Enschede, The Netherlands: ITC.

[24] Vogel, C. and O'Brien, K. 2004. Vulnerability and Global Environmental Change: Rhetoric and Reality. Information Bulletin on Global Environmental Change and Human Security, No. 13. Environmental Change and Security Project and the International Development Research Centre, Ottawa. 